\title{
International Criminal Justice Rendered Concerning the Attack Against Timbuktu Mausoleums and Mosque: Focus on Religion-related Considerations
}

\author{
Dr Juan-Pablo Pérez-León-Acevedo*
}

\section{Introduction}

On 27 September 2016, the International Criminal Court (ICC) Trial Chamber VIII convicted Ahmad al-Faqi al-Mahdi of the war crime of attacking protected objects (ICC Statute, article 8(2)(e)(iv)) ('the war crime'). ${ }^{1}$ Following a plea agreement, al-Mahdi was convicted of intentionally directing attacks against ten religious-historical buildings (nine mausoleums and one mosque) in Timbuktu (Mali) ('the sites' or 'the Timbuktu sites'), between around 30 June 2012 and 11 July 2012, connected to the noninternational armed conflict between state forces and the armed group Ansar Dine (al-Qaeda in the Islamic Maghreb (AQIM)-affiliated) to which al-Mahdi belonged. Al-Mahdi was sentenced to nine years imprisonment. The reconstruction of the sites ended in mid-2015. This was the first ICC judgment concerning the above-mentioned war crime. This comment discusses the legal elements of the war crime, focusing on the religious-historic nature of the sites and the religion-related circumstances of the attacks. It also considers the sentencing criteria, focusing on religion-related considerations.

\section{Attacks against Timbuktu mausoleums and mosque as a war crime}

The article 8(2)(e)(iv) war crime perpetrated was: 'Intentionally directing attacks against buildings dedicated to religion $[\ldots]$ historic monuments provided they are not military objectives'. The ICC Elements of Crimes (ICC-EC) (article 8(2)(e)(iv)1-5) ('war crime of attacking protected objects') set out the legal elements of the war crime. In al-Mahdi, the Chamber proceeded to examine the law as it applied to the facts. ${ }^{2}$

\footnotetext{
Post-Doctoral Fellow, PluriCourts; Faculty of Law, University of Oslo. St. Olavs plass 5, 0165 Oslo. Emails: pe.le.ace@gmail.com / juanpp@jus.uio.no This document was funded by the Research Council of Norway through its Centres of Excellence Funding Scheme Project Number 223274-PluriCourts: The Legitimacy of the International Judiciary. ${ }_{1}^{1}$ Al-Mahdi (ICC-01/12-01/15-171), Judgment and Sentence, 27 September 2016.

2 ibid, para 13 .
} 


\section{A. Objective Legal Elements ${ }^{3}$}

The first objective element is directing 'an attack', including any 'acts of violence against protected objects' whether 'committed both in battle and out of it'. There is no need for a link to particular hostilities but only an association with the conflict more generally. ${ }^{6}$ The fact that the Chamber clarified that the attack may take place regardless of whether or not it is committed during the conduct of hostilities was important in al-Mahdi. The sites were attacked and destroyed not during conduct of hostilities but when Ansar Dine occupied and controlled Timbuktu. The attacks were carried out by alMahdi in order to destroy anything regarded by Ansar Dine as religiously prohibited, particularly buildings constructed above graves (mausoleums) as these were connected to what Ansar Dine regarded as 'superstitious'-related beliefs. As cultural objects, the Timbuktu mausoleums and mosque were protected per se rather than generically as civilian objects, and protected even after the hostilities, ${ }^{7}$ a lex specialis applied. ${ }^{8}$ The ICC Statute and ICC-EC require no result (damage) because it is sufficient that the perpetrators intentionally targeted specific protected objects. ${ }^{9}$ In any event, the Timbuktu sites not only were intentionally targeted but also suffered extensive damage as they were almost completely destroyed during the occupation and control of Timbuktu.

Second, the object of the attack was one or more buildings dedicated to religion, historic monuments, which were not military objectives. Article $8(2)(\mathrm{e})(\mathrm{iv})$ covers several categories of protected buildings, including historic monuments and buildings dedicated to religion. ${ }^{10}$ The sites were of a religious-historical nature. These mausoleums of saints and mosque were central to the religious life of and a common heritage for locals as evidenced by their being frequently visited as places of prayer or pilgrimage by residents. ${ }^{11}$ Besides their status as historic monuments, they were religious buildings with symbolic, emotional and spiritual value for locals. ${ }^{12}$ No military use of the attacked

\footnotetext{
${ }^{3}$ ICC-EC, article 8(2)(e)(iv)(1)(2)(4).

${ }^{4}$ ibid, article 8(2)(e)(1).

${ }^{5}$ Al-Mahdi (n 1) para 15.

${ }^{6}$ ibid., para 18.

${ }^{7}$ ibid, para 16.

${ }^{8}$ William Schabas, The International Criminal Court: A Commentary on the Rome Statute (1st ed, OUP 2010) 235.

${ }^{9}$ Roberta Arnold, 'Article 8(2)(e)(iv)' in Otto Triffterer (ed), Commentary on the Rome Statute of the International Criminal Court (2nd ed, C. H. Beck/Nomos/Hart 2008) 376.

${ }^{10}$ ibid.

${ }^{11}$ Al-Mahdi (n 1) para 34.

12 ibid, paras 46 and 79.
} 
religious-historic buildings was proved or even claimed. All but one of these buildings had belonged to the protected UNESCO World Heritage sites. ${ }^{13}$

Timbuktu sites as religious-historic buildings fall under the Convention for the Protection of Cultural Property in the Event of Armed Conflict (Cultural Property Convention), ${ }^{14}$ supplemented by its Second Protocol, ${ }^{15}$ under which cultural property includes a religious element: '[...] immovable property of great importance to the cultural heritage of every people, such as monuments of architecture, art or history, whether religious or secular $[\ldots] \cdot{ }^{16}$ The Convention obligates states parties to protect, safeguard, and respect cultural property, which arguably also binds non-state groups like Ansar Dine. ${ }^{17}$ Its Second Protocol (article 15) criminalizes serious violations (including extensive destruction of and attacks against cultural property). The attacks against the Timbuktu sites were encompassed by the definition of serious violation within the meaning of the Second Protocol. Although the Second Protocol was not in force for Mali at the time of the attack, the offence was customary international humanitarian law (IHL) at the time. ${ }^{18}$ The sites met the two requirements for their complete protection: property of great importance to the cultural heritage of the people of Timbuktu, identified as dedicated to religion and used for non-military purposes when the attacks took place. $^{19}$

Third, the conduct took place in the context of and associated with a non-international armed conflict. War crimes as serious IHL violations must be linked to armed conflicts. In al-Mahdi, the attacks 'took place in the context of and were associated with' the non-international armed conflict between Malian state forces and non-state armed groups (Ansar Dine/AQIM) ${ }^{20}$ The armed conflict threshold was met as the latter were militarily-capable organised armed groups and exercised control over Timbuktu and its population (Timbuktu occupied and controlled between April 2012 and January 2013), particularly imposing religious edicts via a local government that included an Islamic tribunal,

\footnotetext{
$13<$ http://whc.unesco.org/en/statesparties/ml > accessed 9 October 2016.

${ }^{14}$ Signed on 14 May 1954.

${ }^{15}$ Second Protocol to the Convention for the Protection of Cultural Property in the Event of Armed Conflict, 26 May 1999.

${ }^{16}$ Cultural Property Convention, article 1.

${ }_{17}^{17}$ Marco Sassòli et al, How Does Law Protect in War?, vol 1 (2nd ed, ICRC 2006) 266-268.

${ }^{18}$ Jean-Marie Henckaerts and Louise Doswald-Beck, Customary International Humanitarian Law, vol I (CUP/ICRC 2005) 596-597.

${ }^{19}$ Blaškić, IT-95-14-T, Judgment, 3 March 2000, para 185.

${ }^{20}$ Al-Mahdi (n 1) para 49.
} 
an Islamic police force and a morality brigade (Hesbah). ${ }^{21}$ Sub-categorisation of the non-international armed conflict at the time of the attack remained undiscussed. However, it arguably fell under Protocol II Additional to the Geneva Conventions, ${ }^{22}$ namely, a high-intensity non-international armed conflict.

\section{B. Subjective Legal Elements ${ }^{23}$}

The subjective elements of the war crime include first, that the perpetrator must intend the building(s) dedicated to religion, historic monuments, which were not military objectives, to be the object of the attack. Al-Mahdi knew that he had joint control over the crime and was completely involved in executing it. ${ }^{24} \mathrm{He}$ was viewed as a religion expert, consulted by the Islamic tribunal; wrote on the Hesbah's role and objectives; monitored religious sites; was tasked to prevent, supress, and repressed anything considered to be a prohibited religious practice; and delivered a sermon on destroying the buildings immediately before the attack. ${ }^{25}$ As head of the Hesbah, al-Mahdi led the execution phase of destroying the mausoleums and mosque, and the deliberate manner in which the perpetrators attacked the sites in a relatively short period evidenced their intent to target them ${ }^{26}$ The circumstances of the attack (including common modus operandi) and al-Mahdi's statements that the objective of the attack was to destroy the buildings evidenced the perpetrators' intention to target the sites. ${ }^{27}$

Second, the perpetrator must be aware of factual circumstances concerning the existence of an armed conflict. Al-Mahdi returned to Mali in early April 2012 to support the armed movements in the non-international armed conflict and was in direct contact with Ansar Dine and AQIM leaders. ${ }^{28} \mathrm{Al}-$ Mahdi led the execution of the attack and also personally participated in the destruction, ${ }^{29}$ during the occupation of Timbuktu, that took place in the context of and associated with the Malian noninternational armed conflict .

\footnotetext{
${ }^{21}$ ibid, paras 31 and 49. In February 2015, a cease fire agreement to put an end to the armed conflict in Mali was signed; however, sporadic incidents still continue. See: Peace Direct, 'Mali: Conflict Profile' <https://www.insightonconflict.org/conflicts/mali/conflict-profile/> accessed 13 November 2016.

${ }^{22}$ Protocol Additional to the Geneva Conventions of 12 August 1949, and Relating to the Protection of Victims of NonInternational Armed Conflicts, 8 June 1977, article 1.1.

${ }^{23}$ ICC-EC, article 8(2)(e)(iv)(3)(5).

${ }^{24}$ Al-Mahdi (n 1) para 40.

${ }^{25}$ ibid, paras 32-35 and 54.

${ }^{26}$ ibid, paras 45-47.

${ }^{27}$ ibid, para 48 .

${ }^{28}$ ibid, para 32.

${ }^{29}$ ibid, paras 53-61.
} 


\section{Sentencing Criteria: Focus on Religion-related Elements}

The sentencing criteria with religion-related elements discussed by the Chamber are examined below.

\section{A. Gravity of the Crime}

The Chamber stated that "crimes against property are generally of lesser gravity than crimes against persons $\cdot{ }^{30}$ Although this is arguably the case, there is no hierarchy among ICC-jurisdiction crimes and the Statute's Preamble mentions 'the most serious crimes' without distinguishing between them. Gravity of crimes is actually determined case-by-case. In applying the ICC Statute (article 78.1) and Rules of Procedure and Evidence (rule 145), the Chamber recognized that the extent of damage caused, nature of the unlawful behaviour, and specific circumstances must be considered. ${ }^{31}$ Indeed, the Chamber concluded that al-Mahdi perpetrated a crime 'of significant gravity'. ${ }^{32}$ This wording evidences that the war crime as perpetrated by al-Mahdi not only was among 'the most serious crimes' over which the ICC exercises its jurisdiction but also was significantly grave for sentencing purposes.

The Chamber found the discriminatory religious motive underlying the destruction of the religious sites to be relevant to assess the gravity of the crime. ${ }^{33}$ Under article 18 of the International Covenant on Civil and Political Rights (ICCPR), the right to freedom of religion and belief presents private and public dimensions. ${ }^{34}$ The latter involves active manifestations and includes worship (involving access to places of worship), observance, practice and teaching. ${ }^{35}$ Consequently the destruction of the Timbuktu sites seriously breached locals' right to manifest their religion, and was a direct consequence of Ansar Dine/AQIM's religious measures in occupied Timbuktu (April 2012January 2013). Al-Mahdi headed the Hesbah that imposed religious edicts aimed to eradicate any 'vice' it identified. ${ }^{36}$ After discovering local religious practices and explaining what should not take place at the mausoleums, these sites were destroyed to stop so-called prohibited practices. ${ }^{37}$ Al-Mahdi

\footnotetext{
${ }^{30}$ ibid, para 77.

${ }^{31}$ Ibid, para 76.

32 ibid, para 82

33 ibid, para 81 . See rule $145(2)(b)(v)$.

${ }^{34}$ Manfred Nowak, UN Covenant on Civil and Political Rights. CCPR Commentary (2nd ed, Engel 2005) 410-425.

${ }^{35}$ ibid, 419-421; Human Rights Committee (HRC), CCPR/C/21/Rev.1/Add.4, General Comment No. 2-The right to freedom of thought, conscience and religion (Art. 18), 30 July 1993, para 4. See also Cyprus v Turkey App no 25781/94 (ECtHR Grand Chamber, 10 May 2001) paras 245-246.

${ }_{37}^{36}$ Al-Mahdi (n 1) paras 31 and 81.

${ }^{37}$ ibid, para 81 .
} 
wrote a sermon dedicated to the destruction of the mausoleums, read at the launch of the attack. ${ }^{38}$ The principle of non-discrimination protects persons' freedom to manifest religion or belief from harassment, persecution or hostilities. ${ }^{39}$ This arguably protects those who adopt religious practices not shared by others within the same religion, such as the Timbuktu residents whose religious practices were different to those of Ansar Dine/AQIM.

Thus, gravity of the crime was evidenced by the destruction of places of worship and the related prohibition of religious practices and traditions. The public dimension of freedom of religion and belief in particular was breached during occupation. The Chamber found that the damage was extensive since ten sites were almost completely destroyed, mausoleums, for example, were raised to the ground. These were later reconstructed (2015). Timbuktu was classified by the Chamber as 'an emblematic city with a mythical dimension that played a critical role in the expansion of Islam in the region' ${ }^{40}$ The Chamber considered that the mausoleums of the saints lay at the heart of Mali's cultural heritage, held great importance to locals who admired and were attached to them, and reflected peoples' commitment to Islam playing a psychological role as locals considered themselves as being protected by those sites. ${ }^{41}$ Locals collectively preserved those sites, deeply cherished them and visited them for praying or pilgrimage. ${ }^{42}$ Faithful locals, Malians and the international community were affected. $^{43}$

Accordingly, the Chamber found that the targeted buildings possessed religious, symbolic and emotional value for locals and considered these factors when assessing the gravity of the crime. ${ }^{44}$ Locals protested against the destruction in an attempt to prevent the mausoleums being raised to the ground since such attack aimed to 'break the soul of the people of Timbuktu'. ${ }^{45}$ Among others, UNESCO and NGOs documented the above-mentioned emotional value and the moral and emotional harm caused. ${ }^{46}$ For example, members of Ansar Dine damaged a mosque door to supposedly eradicate

\footnotetext{
${ }^{38}$ ibid, para 32.

${ }^{39}$ Henckaerts and Doswald-Beck (n 18) 378; HRC (n 35) para 2.

${ }^{40}$ Al-Mahdi (n 1) para 78.

41 ibid.

42 ibid.

${ }^{43}$ ibid, para 80.

${ }^{44}$ ibid, para 79 .

45 ibid, para 80.

${ }^{46}$ E.g., Pietro Apollonj-Ghetti, Étude sur les Mausolées de Tombouctou (UNESCO 2014); Human Rights Watch, Collapse, Conflict and Atrocity in Mali, 2014.
} 
idolatry greatly distressing locals. ${ }^{47}$ Locals' particular religious beliefs are protected under ICCPR article 18 as 'religion' and 'belief' is broadly construed and not limited to traditional or mainstream beliefs. $^{48}$

\section{B. Other Sentencing Criteria}

The Chamber considered al-Mahdi's culpable conduct and individual circumstances. ${ }^{49}$ Concerning culpable conduct, al-Mahdi played an essential role in the attack and personally participated in destroying some sites. ${ }^{50}$ While al-Mahdi's initial reluctance to commit the crime was found to be a mitigating factor, no aggravating circumstances were identified since, inter alia, the religious nature of the attack had already caused the crime to be assessed as a grave crime. ${ }^{51}$ Since rule $145(2)(\mathrm{b})(\mathrm{vi})$ contains an open-ended aggravating circumstance clause ('other circumstances'), this finding is criticized herein on the grounds that it was open to the Chamber to find there were aggravating circumstances. This is because the crime committed required no material damage. Consequently the Chamber should have examined whether the extensive damage caused was an aggravating factor.

The nature of the victims, including their defencelessness and the numbers affected by the crime ${ }^{52}$ may also be considered as aggravating circumstances. Since the war crime targeted objects, double-layered victimhood could have been considered. This is because at the ICC, victims can be 'natural persons' who suffered harm resulting from the crime, and 'organizations or institutions' that have sustained direct harm of their property dedicated to, inter alia, religion and historic monuments. ${ }^{53}$ The Chamber authorized individuals and organizations to participate and claim reparations in alMahdi ${ }^{54}$ however, it did not accurately determine the relevant categories of victims of the war crime. The Chamber judgment identified both the sites and 'natural persons' as direct victims. ${ }^{55}$ The concepts of 'direct' victim (harm results from an ICC-jurisdiction crime) and 'indirect' victim (harm results

\footnotetext{
${ }^{47}$ Al-Mahdi (n 1) para 38.viii.

${ }^{48} \mathrm{HRC}$ (n 35) para 2.

${ }^{49}$ ICC Statute, article 78(1); rule 145.

${ }^{50}$ Al-Mahdi (n 1) paras 84-85.

${ }^{51}$ ibid, paras $88-89$.

${ }^{52}$ Rule 145(2)(b)(iii)-(iv).

${ }^{53}$ Rule 85.

${ }^{54}$ Al-Mahdi (ICC-01/12-01/15-97-Red), Decision on Victim Participation at Trial and on Common Legal Representation of Victims, 8 June 2016; Al-Mahdi (ICC-01/12-01/15-156-Red), Second Decision on Victim Participation at Trial, 12 August 2016.

${ }^{55}$ Al-Mahdi (n 1) paras 67 and 80.
} 
from the harm suffered by direct victims $)^{56}$ are useful here. Whereas the Timbuktu sites were direct victims, persons were indirect victims. The Chamber judgment inaccurately categorised the 'faithful and inhabitants of Timbuktu' as direct victims. ${ }^{57}$ Locals saw their (public) freedom of religion and belief seriously breached and suffered emotional and moral harm. Had they been classed as indirect victims (the Timbuktu sites were direct victims), it would then have been possible to better approach the nature and scope of victimhood in al-Mahdi and examine whether this was an aggravating circumstance. 'Defencelessness' of victims, 'multiple victims' or 'other circumstances' (rule 145(2)(b)(iii), (iv) and (vi) respectively) could have been considered.......

Furthermore, al-Mahdi intentionally committed serious customary IHL violations concerning respect for religious-historic buildings and important cultural heritage property, and respect for convictions and religious practices of civilians. ${ }^{58} \mathrm{He}$ also violated Additional Protocol II (article 4(1)). This recognises the right to respect for 'convictions and religious practices'. Under a 'horizontal effect' interpretation of ICCPR article 18(2), states are obliged to prevent private coercion of another to have or adopt certain religious beliefs. ${ }^{59}$ Additionally, certain international human rights law principles may arguably bind non-state actors, particularly during occupation and control of a territory. ${ }^{60}$ During the occupation and control of Timbuktu by Ansar Dine/AQIM, which Mali could not stop, alongside others al-Mahdi in his individual capacity exercised coercion, and disregarded the right to freedom of religion or belief of the people. ${ }^{61}$ The fact that al-Mahdi committed serious violations of both customary IHL and certain international human rights law principles could have been examined under 'other circumstances' as an aggravating factor.Strict conditions to limit the public dimension of the right to religious freedom in public emergencies (Malian NIAC

Concerning individual circumstances, the Chamber dismissed al-Mahdi's status as a religious scholar and expert. Although his background could have been considered as an aggravating circumstance in order to increase his sentence, the Chamber's approach can be seen as rightly

\footnotetext{
${ }^{56}$ Lubanga (ICC-01/04-01/06-1813), Redacted version of "Decision on “indirect victims"”, 8 April 2009, para 44.

${ }^{57}$ Al-Mahdi (n 1) para 80.

${ }^{58}$ Henckaerts and Doswald-Beck (n 18) 127-130 and 375-379.

59 Sarah Joseph and Melissa Castan, The International Covenant on Civil and Political Rights: Cases, Materials and Commentary (3rd edn, OUP 2013) 505; Nowak (n 34) xxi.

${ }^{60}$ Andrew Clapham, 'Human rights obligations of non-state actors in conflict situations' (2006) 88 International Review of the Red Cross 491, 495-508; Gerd Oberleitner, Human Rights in Armed Conflict: Law, Practice, Policy (CUP 2015$) 211-219$.

${ }^{61}$ ICCPR, articles 4 and $18(3)$.
} 
balanced regarding his positive role in his community before the events of this case. The Chamber appropriately found that al-Mahdi's admission of guilt was a mitigating factor. This was because it might have alleviated 'the victims' moral suffering' by acknowledging the importance of the destruction. ${ }^{62}$ Also because it might have deterrent effects by preventing attacks against religioushistoric buildings in future. ${ }^{63}$ It also signified substantial cooperation, remorse and empathy for the victims. $^{64}$

\section{Conclusion}

Al-Mahdi is an important decision because the ICC sent a strong message of zero tolerance for attacks against religious-historic buildings in an international context characterized by armed conflicts in which non-state actors have intentionally attacked and destroyed religious-historic sites. It provides a reference point for similar acts carried out in Syria, Iraq and Afghanistan. Besides retribution and deterrence ${ }^{65}$ international criminal prosecution of intentional attacks against religious-historic sites may become an important avenue to protect the right to freedom of religion and belief, especially when non-state actors are involved. Destroying religious-historic sites, as part of or in addition to the prohibition of religious practices, breaches or affects freedom of religion. Al-Mahdi thus creates a useful precedent for identifying religion-related connections where international law obligations are infringed.

\footnotetext{
${ }^{62}$ Al-Mahdi (n 1) para 100.

${ }^{63}$ ibid, para 103.

${ }^{64}$ ibid, paras 101-105.

${ }^{65}$ ibid, para 67.
} 